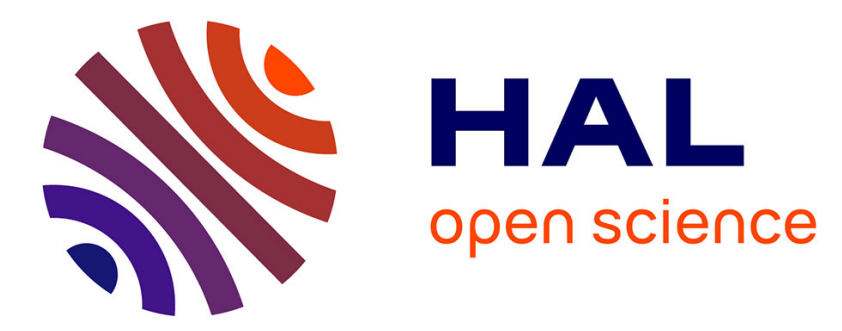

\title{
Improved U-Th dating of carbonates with high initial 230Th using stratigraphical and coevality constraints
}

Matthieu Roy-Barman, Edwige Pons-Branchu

\section{To cite this version:}

Matthieu Roy-Barman, Edwige Pons-Branchu. Improved U-Th dating of carbonates with high initial $230 \mathrm{Th}$ using stratigraphical and coevality constraints. Quaternary Geochronology, 2016, 32, pp.29 39. 10.1016/j.quageo.2015.12.002 . hal-01587391

\section{HAL Id: hal-01587391 \\ https://hal.science/hal-01587391}

Submitted on 1 Mar 2021

HAL is a multi-disciplinary open access archive for the deposit and dissemination of scientific research documents, whether they are published or not. The documents may come from teaching and research institutions in France or abroad, or from public or private research centers.
L'archive ouverte pluridisciplinaire HAL, est destinée au dépôt et à la diffusion de documents scientifiques de niveau recherche, publiés ou non, émanant des établissements d'enseignement et de recherche français ou étrangers, des laboratoires publics ou privés. 
1 stratigraphical and coevality contraints

Matthieu Roy-Barman* and Edwige Pons-Branchu

Laboratoire des Sciences du Climat et de l'Environnement

LSCE/IPSL, CEA-CNRS-UVSQ, Université Paris-Saclay

F-91198 Gif-sur-Yvette, France

Quaternary Geochronology, Volume 32, April 2016, Pages 29-39

\footnotetext{
*Corresponding author (Matthieu.Roy-Barman@ lsce.ipsl.fr)
} 
2

3

4

5

6

\section{Abstract}

With high precision measurements now achievable by MC-ICPMS, the uncertainty on the initial ${ }^{230}$ Th content can be the major source of uncertainty for U-Th ages of carbonates. The initial ${ }^{230}$ Th content is usually derived from the ${ }^{232}$ Th content of the sample and the initial ${ }^{230} \mathrm{Th} /{ }^{232} \mathrm{Th}$ ratio calculated using isochron techniques or using stratigraphical constraints along the speleothem growth axis. These two methods are based on different hypotheses and have not been couple previously. Here, we present a new algorithm called STRUTages that combines stratigraphical and coevality constraints in order to obtain the best estimate on the initial ${ }^{230} \mathrm{Th} /{ }^{232} \mathrm{Th}$ ratio of each sample. STRUTages and isochron results are compared on a suite of speleothems and a coral core. Comparison of the U-Th and growth-band counted ages of the coral core demonstrates the validity of the STRUTages approach. An Octave (Matlabcompatible) script allowing the use of stratigraphical and coevality constraints is provided.

Keywords: STRUTages; U-Th dating; speleothem; coral; isochron; stratigraphical; coeval constraints

\section{Highlights :}

* We present a new method to constrain the initial ${ }^{230}$ Th content of coeval samples.

* It is compatible with the stratigraphical constraint method of Hellstrom (2006).

* Combination of both methods allows an improved dating of carbonates.

* The method is validated on independently dated (growth band counting) samples.

* A script performing both stratigraphical and coeval sample constraints is provided. 
1

2

3

4

5

6

7

8

9

\section{Introduction}

The ${ }^{230} \mathrm{Th}_{-}{ }^{234} \mathrm{U}_{-}{ }^{238} \mathrm{U}$ dating method is widely applied to carbonate samples (speleothems, corals). It generally allows an accurate determination of the age of these paleoclimatic and paleoenvironmental archives over the last $500 \mathrm{ka}$. This method assumes that the carbonate has remained a closed system since its formation and that all the ${ }^{230} \mathrm{Th}$ in the sample comes from the radioactive decay of ${ }^{234} \mathrm{U}$. However, for speleothems and to a lesser extent for corals, this last assumption is often false and this can have a significant effect on the apparent age, particularly for young $(<50 \mathrm{ka})$ speleothems and/or speleothems with a low $\mathrm{U}$ content and/or a high detrital Th content. It is therefore necessary to correct for the ${ }^{230} \mathrm{Th}$ present in the carbonate at the time of its formation. It becomes all the more critical with the high analytical precision provided by MC-ICPMS, the U-Th content of most carbonate sample can be determined at a permil or sub-permil level, so that the uncertainty on the initial ${ }^{230} \mathrm{Th}$ content of the speleothem becomes a significant, if not prominent, source of uncertainty on the age (Dorale et al., 2004).

The degree of ${ }^{230} \mathrm{Th}$ initial is generally indicated by the presence of ${ }^{232} \mathrm{Th}$. In early studies, it was assumed that samples with $\left({ }^{230} \mathrm{Th} /{ }^{232} \mathrm{Th}\right)$ activity ratio $>20$ did not require corrections (Bischoff and Fitzpatrick, 1991). However, with the improvement of dating technics, more recent studies propose with that the influence of this detrital fraction on age determination is significant for measured $\left({ }^{230} \mathrm{Th} /{ }^{232} \mathrm{Th}\right)$ activity ratio as high as 300 (Hellstrom, 2006).

It is possible to deduce and subtract the initial ${ }^{230} \mathrm{Th}$ content of a speleothem or a coral from its ${ }^{232} \mathrm{Th}$ content, if the initial ${ }^{230} \mathrm{Th} /{ }^{232} \mathrm{Th}$ activity ratio is known. This initial ${ }^{230} \mathrm{Th} /{ }^{232} \mathrm{Th}$ activity ratio can be estimated or determined by measurements. The average crustal U/Th ratio combined with the assumption that ${ }^{230} \mathrm{Th}$ is in secular equilibrium with ${ }^{238} \mathrm{U}$ has been 
1 widely used to estimate the initial ${ }^{230} \mathrm{Th} /{ }^{232} \mathrm{Th}$ activity ratio. However, several studies have

2 demonstrated that this value does not reflect the whole range of initial Th activity ratio,

3 because clay is not the only Th source (e.g. Beck et al., 2001; Hellstrom 2006) and because

4 the U/Th ratio in detrital particles and colloids can vary strongly (Marchandise et al, 2014).

5 Drip water in caves, sea water or modern calcium carbonate are also used to determine the

6 initial Th activity ratio $\left({ }^{230} \mathrm{Th} /{ }^{232} \mathrm{Th}\right)_{A 0}$ at the formation of the speleothem (Hu et al., 2008,

7 Wortham et al., 2013). This initial ratio can also be deduced directly from an isochron

8 constructed with several subsamples from the same laminae (or group of laminae) of the

9 speleothem having different U/Th ratios (Dorale et al., 2004). However, $\left({ }^{230} \mathrm{Th} /{ }^{232} \mathrm{Th}\right)_{A 0}$

obtained on one stratigraphical level with an isochron or by the measurement of modern

calcite or aragonite may not be valid throughout the speleothem or coral. More recently, the

"stratigraphical constraint" method was developed to determine the range of $\left({ }^{230} \mathrm{Th} /{ }^{232} \mathrm{Th}\right)_{A 0}$ that keeps speleothem samples in stratigraphical order after correction for the initial ${ }^{230} \mathrm{Th}$ content (Hellstrom, 2006). These two methods require different sample set: the isochron

method uses several samples of the same age, whereas the stratigraphical method uses several samples of different ages. The isochron method is widely used and many researchers draw upon the freely-available software I soplot (Ludwig, 2003) to calculate $\left({ }^{230} \mathrm{Th} /{ }^{232} \mathrm{Th}\right)_{A 0}$ in an isochron diagram. On the other hand, no software performing the "stratigraphical constraint" method has been published so far.

Recently, we developed our own routine to obtain stratigraphical constraints on very young ( $<400$ a) and detritus-rich speleothems (Pons-Branchu et al., 2014). Initially, our goal was to reproduce the method described in Hellstrom (2006). However, it rapidly appeared that a program would be much more practical if it could combine samples of increasing ages through the speleothem (the stratigraphical method) with samples from the same stratigraphical level (hereafter called subsamples), whether they are "replicates" of a given 
1 layer or they are purposefully analyzed to obtain an isochron (generally, $n>2$ ). This

2 corresponds to the effective sampling of many speleothems, indeed (Ersek et al., 2009).

3 Beyond the practical aspect of treating coeval and non-coeval samples, we primarily aim at

4 better constraining the initial ${ }^{230} \mathrm{Th}$ content of the speleothem by combining the information

5 brought by all available samples in a self-consistent manner. Indeed, it is not straightforward

6 to combine the uncertainties obtained on the same speleothem by isochron(s) and

7 stratigraphical constraints because these two methods are based on different assumptions and 8 they use common information so that they are not independent and related in a complex 9 manner.

We have developed a new method to evaluate the age of coeval subsamples. This method is compatible in terms of assumptions and calculation process with the stratigraphical method developed by Hellstrom (2006). Here, we describe this method, present a few applications illustrating the possibility and limits of the method and provide an open source program called STRUTages (STRatgraphical and coeval constraints on U-Th ages) that allows applying the stratigraphical constraint method (with or without coeval sub-samples) to a broad range of datasets.

\section{Method}

2.1. Principle of the stratigraphical constraints from non-coeval samples the stratigraphical method developed by Hellstrom (2006), which is based on a Monte Carlo simulation (see description in Albarède, 1995, for example). Monte Carlo estimates of errors of a function are obtained by repeatedly perturbing ( $\mathrm{N}$ trials) the input data according to their assigned errors and error distribution. At each trial, random values are generated to simulate: 
1

2

3

4

1- measured ${ }^{234} \mathrm{U} /{ }^{238} \mathrm{U},{ }^{232} \mathrm{Th} /{ }^{238} \mathrm{U}$ and ${ }^{230} \mathrm{Th} /{ }^{238} \mathrm{U}$ activity ratios expressed as $\left({ }^{234} \mathrm{U} /{ }^{238} \mathrm{U}\right)_{\mathrm{A}},\left({ }^{232} \mathrm{Th} /{ }^{238} \mathrm{U}\right)_{\mathrm{A}}$ and $\left({ }^{230} \mathrm{Th} /{ }^{238} \mathrm{U}\right)_{\mathrm{A}}$ (with Gaussian distributions centered on the mean measured ratios and with two standard deviations $(2 \sigma)$ of the distribution given by the two standard deviation on the measured ratios). There is no covariance between these ratios, so $\alpha$-counting data cannot be treated with STRUTages.

2- Mean $\left({ }^{230} \mathrm{Th} /{ }^{232} \mathrm{Th}\right)_{\mathrm{A} 0}$ of the speleothem: $\mathrm{R}_{\mathrm{i} \_ \text {mean }}$. This is chosen from a large range of plausible values (exponential distribution of the activity ratio ranging from 0.1 to 30 )

3- Maximum percentage of variability of $\left({ }^{230} \mathrm{Th} /{ }^{232} \mathrm{Th}\right)_{\mathrm{A} 0}$ within the speleothem (uniform distribution ranging from $0 \%$ to $100 \%$ ): $\Delta \mathrm{R}_{\mathrm{i}}$.

4- For each sample analyzed in the speleothem, a specific $R_{i}$ within the range defined by $\mathrm{R}_{\mathrm{i} \_ \text {mean }}$ and by the maximum percentage of variability $\Delta \mathrm{R}_{\mathrm{i}}$ : uniform distribution ranging from $\mathrm{R}_{\mathrm{i} \_ \text {mean }}-\Delta \mathrm{R}_{\mathrm{i}}$ to $\mathrm{R}_{\mathrm{i} \_ \text {mean }}+\Delta \mathrm{R}_{\mathrm{i}}$.

Step 4 defines the individual $\left({ }^{230} \mathrm{Th} /{ }^{232} \mathrm{Th}\right)_{\mathrm{A} 0}$ ratios $\left(\mathrm{R}_{\mathrm{i}}\right)$ of each simulated sample of the speleothem within the range determined by steps 2 and 3 .

Step 5: trials with no physical meaning (if they are just due to the statistical uncertainties on the analyses) or corresponding to an open system behavior were discarded. This was the case when:

- $\left({ }^{230} \mathrm{Th} /{ }^{238} \mathrm{U}\right)_{\mathrm{A}}<\left({ }^{232} \mathrm{Th} /{ }^{238} \mathrm{U}\right)_{\mathrm{A}} \times \mathrm{R}_{\mathrm{i}}$ (i.e. less ${ }^{230} \mathrm{Th}$ in the sample today than at the time of formation)

- $\left({ }^{230} \mathrm{Th} /{ }^{238} \mathrm{U}\right)_{\mathrm{A}}-1>\left(\left({ }^{234} \mathrm{U} /{ }^{238} \mathrm{U}\right)_{\mathrm{A}}-1\right) \times \lambda_{230} /\left(\lambda_{230}-\lambda_{234}\right)$ (i.e. sample plotting on the right of the infinite age line in a $\left({ }^{230} \mathrm{Th} /{ }^{238} \mathrm{U}\right)_{\mathrm{A}}$ versus $\left.\left({ }^{234} \mathrm{U} /{ }^{238} \mathrm{U}\right)_{\mathrm{A}}-1\right)$ diagram and corresponding to the "forbidden zone" for which no finite age exists). 
Sample ages were calculated for each trial with the randomized values obtained at steps 1 and 5, by solving numerically the equation:

$$
\left({ }^{230} T h /{ }^{238} U\right)_{A}=1-e^{-\lambda_{230}}\left(1-\left({ }^{232} T h /{ }^{238} U\right)_{A} \times\left({ }^{230} T h /{ }^{232} T h\right)_{A 0}\right)
$$

$$
+\left(\left({ }^{234} U /^{238} U\right)_{A}-1\right)\left(\frac{\lambda_{230}}{\lambda_{230}-\lambda_{234}}\right)\left(1-e^{-\left(\lambda_{230}-\lambda_{234}\right) t}\right)
$$

Any trial in which the calculated ages were not in the stratigraphical order or in which negative ages were obtained were discarded (Fig. 1a,b). From $10^{4}$ to $10^{10}$ iterations were performed to obtain at least a few hundred valid solutions with positive ages in the stratigraphical order. Only these valid iterations were averaged to determine the most probable ages and $\left({ }^{230} \mathrm{Th} /{ }^{232} \mathrm{Th}\right)_{\mathrm{A} 0}$ in the speleothem or coral (hereafter called "archive").

For a given $R_{i \_m e a n}-\Delta R_{i}$ pair, a single successful trial is a sufficient condition to guarantee that the samples can be in stratigraphical order within the analytical uncertainties (Fig. 1.a). However, it is not a necessary condition because a single trial does not cover the whole range of uncertainty on each sample age (Fig 1.b). Nevertheless, with the large number of trails performed, it is likely that the successful trails should allow a reasonable mapping of the valid $R_{i_{-} \text {mean }}-\Delta R_{i}$ pairs.

When two or more coeval subsamples from the same stratigraphic level are present in the speleothem or the coral, two different constraints can be used to account for these subsamples: the loose coevality constraints and the strict coevality constraints. We describe these in the following sections. 
1 2.2. Weak constraints for "loosely" coeval samples: the loose coevality constraints

When two or more subsamples of the same stratigraphical level of the archive are analyzed, they are not compared to each other. They are just compared with the sample of the previous and of the next stratigraphic level. The ages of these subsamples are simply replaced by a doublet made of the lowest and the highest ages among the subsamples. This doublet then replaces the whole subsamples suite in the sample series for the stratigraphical age test.

This treatment corresponds to a weak constraint imposed by the subsamples on $\mathrm{R}_{\mathrm{i} \_ \text {mean }}$ and $\Delta \mathrm{R}_{\mathrm{i}}$. The subsamples just have to be younger than the sample from the previous (older) level and older than the next sample (younger) level. However, these subsamples do not have to have the same age. It corresponds to a situation where the replicates were sampled in an area where the laminae are poorly visible and/or of very slow growth rate, so that the synchronicity of the "replicates" is not certain. From the modeling point of view, it provides a screening of $R_{i \_m e a n}-\Delta R_{i}$ pairs allowing the stratigraphical order of the samples. These pairs will be used in the next step to add up age constraints on coeval subsamples.

2.3. Strong constraints for strictly coeval samples: the strict coevality constrain.

When subsamples of one or several stratigraphical levels are present, we add new constraints: the ages of all the subsamples from the same level must be equal within analytical uncertainties (Fig. 1ef). We note that it is not sufficient to take the intersection of the age ranges of the subsamples calculated in Section 2.3., because the initial ${ }^{230}$ Th correction introduces a strong covariance between the ages of the subsamples (see Section 3.2). This effect can be easily understood by considering two subsamples with partly overlapping error bars after the "loose coevality constraints" test: discarding trials with the oldest ages of the 
1 oldest subsamples (these ages stand above the age intersection of the subsamples) will also

2 discard the oldest ages of the youngest subsample (although they belonged to the common age

3 range) because all these ages are likely to have been obtained with same the lowest $R_{i_{-} \text {mean }}$

4 values. Hence, two replicates having a common age range with the "loose coevality

5 constraints" may end up with significantly smaller age ranges after the "strict coevality

6 constraints". In some case, the overlapping may disappear and the trial is then discarded.

In the previous sections, at each trial, the stratigraphical test was based on only one randomly-chosen age of each sample because it was sufficient to set ages in order, but it is not sufficient to determine if the subsample ages are equal. The age range of each sample was obtained by compiling the age of the successful trials.

We must now determine for each successful $R_{i \_m e a n}-\Delta R_{i}$ pairs obtained at the Section 2.2. if the subsample ages are equal within uncertainties. For each successful pair, the $\left({ }^{234} \mathrm{U} /{ }^{238} \mathrm{U}\right)_{\mathrm{A}},\left({ }^{232} \mathrm{Th} /{ }^{238} \mathrm{U}\right)_{\mathrm{A}}$ and $\left({ }^{230} \mathrm{Th} /{ }^{238} \mathrm{U}\right)_{\mathrm{A}}$ are randomized about 1000 times and used to calculate the age range of each sample (subsamples or not). The age ranges of all replicates from the same layer are then compared to determine their intersection. Only trials with all ages in the stratigraphical order and replicate ages within the replicate age intersection are selected as valid. All other trials are discarded. Hence, we obtain for each sample and subsample an age range that fulfill within the analytical uncertainties both the stratigraphical order for sample from different layers and the synchronicity of subsamples of a given stratigraphical level.

\subsection{Computing considerations}


2 (http//www.gnu.org/software/octave/). Octave is compatible with Matlab and it can be

The program was computed using the Octave freeware enabled on Linux, OS X, BSD and Windows operating systems. Here we use Octave 4.0.0 on

a PC computer with the Windows operating system. Due to the large number of trials (up to $10^{10}$ ) required to obtain enough valid solutions, constraints exist for both the running time of the program and the number of trials that can be stored in the memory.

The calculation time was optimized by using matrix operations whenever it was possible. Equation 1 was solved numerically to obtain the sample ages. We initially used the built-in functions of Octave (fsolve and fzero) to solve Equation 1. However, they turned out to be slow when solving a large number of equations. Therefore, we used the NewtonRaphson algorithm that generally converges rapidly and that can be written under a matrix form to solve thousands of equations simultaneously (Albarède, 1995, Quarteroni and Saleri, 2006). The effectiveness of the algorithm convergence was tested by: - calculating the evolution of the $\left({ }^{234} \mathrm{U} /{ }^{238} \mathrm{U}\right)_{\mathrm{A}}$ and $\left({ }^{230} \mathrm{Th} /{ }^{238} \mathrm{U}\right)_{\mathrm{A}}$ activity ratios in a closed system with prescribed values of the $\left({ }^{234} \mathrm{U} /{ }^{238} \mathrm{U}\right)_{\mathrm{A} 0}$ activity ratio ranging from 0.8 to 10 , of the prescribed $\left({ }^{230} \mathrm{Th} /{ }^{238} \mathrm{U}\right)_{\mathrm{A} 0}$ activity ratio equal to zero and for prescribed ages ranging from 1 a to $800 \mathrm{ka}$ which are, effectively, the lower and upper limits to use U-Th dating. The $\left({ }^{232} \mathrm{Th} /{ }^{238} \mathrm{U}\right)_{\mathrm{A}}$ ratio was set to zero because the purpose was only to check the algorithm convergence.

- recalculating the sample age with $\left({ }^{234} \mathrm{U} /{ }^{238} \mathrm{U}\right)_{\mathrm{A}}$ and $\left({ }^{232} \mathrm{Th} /{ }^{238} \mathrm{U}\right)_{\mathrm{A}}$ as input values - comparing prescribed and calculated ages.

The calculated age deviates from the true age by less than $0.001 \%$ for a sample of $1 \mathrm{a}$ and no more than $0.1 \%$ for a sample of $800 \mathrm{ka}$. This is negligible compared to the propagation of statistical uncertainties on the measurement. There is very good agreement 
between the ages calculated on individual samples by STRUTages and Isoplot (Tab. 1), as illustrated by 2 numerical examples derived from Ludwig (2003).

The STRUTages.m (Santa Elina data) and STRUTages_acc.m (Newton algorithm accuracy test) scripts and the user manual are given in electronic supplements.

\subsection{Carbonate samples for program testing}

In the following, the impact of the age correction model on carbonate dating is illustrated by two speleothems in contrasting environments and one coral core:

- A detritus-rich and young speleothem sampled in the Santa Elina prehistoric shelter $\left(15^{\circ} 28^{\prime} \mathrm{S}, 56^{\circ} 48^{\prime} \mathrm{W}\right.$, Mato Grosso, Brasil). In this $9 \mathrm{~cm}$-long stalagmite, laminated and porous zones alternate. U-Th data suggests ages younger than $10 \mathrm{ka}$ (Pons-Banchu and Fontugne, unpublished data), whereas stratigraphically-ordered ${ }^{14} \mathrm{C}$ ages suggest that the speleothem age is less than 560 a (Fontugne, unpublished data). This is an upper limit because no dead carbon correction is applied for these young ages. In this speleothem, three stratigraphical levels were analyzed. For one of these level, 3 subsamples were analyzed (Table ES1 in the electronic supplement).

- A detrital-rich and young (<5500 a) speleothem sampled in the Rupt du Puits cave in the East of France (Pons-Banchu, 2001; Jaillet et al., 2006). This speleothem developed in an active karstic system covered by Cretaceous deposits (clay and sands). Eight stratigraphical levels of this speleothem were analyzed (Table ES2 in the electronic supplement). For one of these levels, three subsamples were analyzed.

- A subtidal coral core (92MC) from the Espiritu Santo island (Vanuatu) in the Eastern Pacific ocean (Shen et al., 2008). The coral material expected to be less than 100 years old. It lived in an open-ocean environment with no direct riverine inputs. However, the ${ }^{230} \mathrm{Th} /{ }^{232} \mathrm{Th}$ ratio of 
1 the local seawater varies due to deep water upwelling during La Nina events. It has been dated

2 by both U-Th and band-counting in order to test the accuracy of young U-Th ages. Therefore,

3 it gives a unique opportunity to test the STRUTages method. Six stratigraphical levels were

4 analyzed in this core (Table ES3 in the electronic supplement). Four sub-samples were

5 analyzed for each of the two youngest levels:

- Subsamples (1\#a to $1 \# \mathrm{~d})$ of the youngest level with an age of $13 \pm 0.5 \mathrm{a}$ determined by growth band counting do not plot on a single isochron (Shen et al., 2008). Three subsamples ( $1 \#$ a to $1 \# \mathrm{c}$ ) yield an acceptable isochron age of $12 \pm 1.3$ a and an initial activity ratio $R_{i}=1.0$. The age of the other subsample $(1 \# d)$ when corrected with a $R_{i}$ value of 1.0 and yielded an age of $19.0 \pm 1.2$ a. This overestimated age comes from an underestimation of the $R_{i}$ value of this subsample which may have grown during a short upwelling event (see below).

- Four subsamples (2\#a to $2 \# d$ ) with an age of the $30.5 \pm 0.5$ a determined by growth band counting yield an isochron age of $29.2 \pm 1.3 \mathrm{a}$ and $\mathrm{R}_{\mathrm{i}}=4.5$. This high $\mathrm{R}_{\mathrm{i}}$ value may be related to the upwelling of deep water Shen et al. (2008).

\section{Results}

For each archive, we first present the ages calculated with strict coevality constraints only and we compare them with isochron ages obtained with Isoplot. Then, we present the results obtained with the STRUTages with the loose and strict coevality constraints on the whole sample set. Uncertainties on age and $R_{i}$ are given as $95 \%$ probability errors $\left(5^{\text {th }}\right.$ and $95^{\text {th }}$ percentiles because some age and $R_{i}$ distributions are not Gaussian). Combining the mean (normally associated with the standard deviation) and percentiles (normally associated with 
1 the median) may appear mathematically heterodox, but it is consistent with Isoplot format

2 for non-Gaussian age distributions (Ludwig, 2003).

3 3.1. Santa Elina

4

U-Th ages $(2.39 \pm 0.28,2.36 \pm 0.29$ and $2.37 \pm 0.22 \mathrm{ka})$ of the three coeval subsamples obtained with the strict coevality constraints are compatible within the uncertainty of the isochron age of $2.3 \pm 2.5$ ka calculated with suing Isoplot.

The five samples can be placed in stratigraphical order for very low values of the $\Delta R_{i}$ $(<1 \%)$ with or without coeval subsample constraints (Table 2, Figure 2a). There is a clear decrease in the uncertainties of ages when coeval subsample constraints are included (Figure $2 b$ ). This goes together with a reduction of the range $R_{i}$ values when coeval subsample constraints are included. We note that the ages of the three coeval subsamples are identical and have identical uncertainties whether they are calculated with or without the stratigraphical constraints of the other samples. It means that in the case of Santa Elina, the age constraints come only from the three coeval samples at the top of the speleothem and that putting these samples in stratigraphical order with the 2 older samples brings no more constraints on age and $\mathrm{R}_{\mathrm{i}}$.

\subsection{Rupt du Puits}

The age of the three coeval subsamples of the Rupt du Puits speleothems are not very precisely constrained $(\approx 5.3 \pm 0.4 \mathrm{ka})$ by the coeval constraints alone because there is an insufficient range of ${ }^{232} \mathrm{Th}^{2}{ }^{238} \mathrm{U}$ for the samples (Table 3). This age is consistent within uncertainties with the isochron age obtained with Is p p ot $(5.6 \pm 0.7 \mathrm{ka})$. The ages obtained with the stratigraphical constraints alone $(4.92+0.15 /-0.16 \mathrm{ka}, 4.8+0.13 /-0.12 \mathrm{ka}, 4.94$ $+0.14 /-0.15 \mathrm{ka}$ ) fall on the low end of the estimates made with the coeval constraints alone. 
1 The stratigraphical constraints give smaller uncertainties (Fig; 3, Tab. 3) due to the occurrence

2 of much larger range of ${ }^{232} \mathrm{Th} /{ }^{238} \mathrm{U}$ fractionation along the speleothem (up to a factor 50).

3 Adding the strict constraints of coeval samples to the stratigraphical constraints provides a

4 small but significant improvement of the uncertainty of about $10 \%$ for each sample.

5

6

7

8

\subsection{Santo coral core}

It is not possible to obtain successful simulations for the four subsamples of the youngest stratigraphical level or for the whole speleothem with $\Delta \mathrm{R}_{\mathrm{i}}$ values lower than $\approx 50 \%$. (Fig. 4). Therefore, we calculate ages and $R_{i}$ values for $\Delta R_{i}<70 \%$. This value was chosen a priori and somewhat arbitrarily.

The ages determined by STRUTages on the two sets of subsamples of the first and second levels are consistent within uncertainties with the ages determined with Isoplot. As for the Santa Elina and for the Rupt du Puits speleothems, uncertainties determined by STRUTages are generally (4 point data sets of level 1 and 2) smaller than uncertainties determined with Isoplot of the coral core. However, very consistent results are obtained for the 3 point data set of the youngest level by STRUTages $(14.2+1.5 /-1.1 \mathrm{y}, 14.1+0.9 /-0.8$

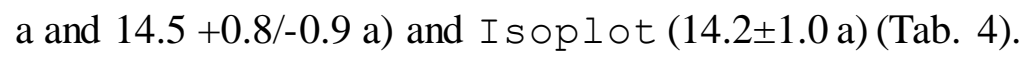

All the ages calculated by STRUTages with the coeval subsample constraints agree within uncertainties with the ages determined by band counting (Figure 5).

\section{Discussion}

4.1 Comparing STRUTages with isochron ages for coeval subsamples 
Isochrones are the most appropriate method to determine the age of coeval samples (e.g. Allègre, 2008). Therefore, it is important to compare STRUTages ages with isochron ages. Since ${ }^{230} \mathrm{Th}$ and ${ }^{234} \mathrm{U}$ are both radioactive and radiogenic, isochron age determination is often done by drawing isochrons in the $\left({ }^{230} \mathrm{Th} /{ }^{238} \mathrm{U}\right)_{\mathrm{A}}$ versus $\left({ }^{232} \mathrm{Th} /{ }^{238} \mathrm{U}\right)_{\mathrm{A}}$ and $\left({ }^{234} \mathrm{U} /{ }^{238} \mathrm{U}\right)_{\mathrm{A}}$ versus $\left({ }^{232} \mathrm{Th} /{ }^{238} \mathrm{U}\right)_{\mathrm{A}}$ diagrams or other diagram pairs that completely define the ${ }^{234} \mathrm{U}-{ }^{238} \mathrm{U}$ ${ }^{230} \mathrm{Th}-{ }^{232} \mathrm{Th}$ system (Geyh, 2008). However, full uncertainty propagation is difficult with paired diagrams because they share common information. This difficulty is circumvented by considering a single isochron line in three-dimensional space, i.e $\left({ }^{230} \mathrm{Th} /{ }^{238} \mathrm{U}\right)_{\mathrm{A}}-\left({ }^{234} \mathrm{U} /{ }^{238} \mathrm{U}\right)_{\mathrm{A}^{-}}$ $\left({ }^{232} \mathrm{Th} /{ }^{238} \mathrm{U}\right)_{\mathrm{A}}$, which can be done using the Isoplot program (Ludwig and Titterington, 1994, Ludwig, 2003).

The three fundamental assumptions of an isochron are that (1) the samples must have been formed at the same time, (2) their parent and daughter isotope ratios were initially homogeneous which corresponds to a single source of initial $R_{i}$ and (3) they have behaved as a closed-system. When sample scattering around the isochron exceeds analytical errors, at least one of the following failures affects the samples: 1) multiple detrital components (Dorale et al. 2004), 2) multiple ages, or 3) an open-system history (Borsato et al., 2003).

In contrast to the single $\mathrm{R}_{\mathrm{i}}$ value (corresponding to a single detrital source) assumption of the isochron method, the basis of the age calculation with the strict coevality constraints is to adjust the $R_{i}$ ratio of each subsample in order to obtain a common age for all these subsamples. With different assumptions, STRUTages and isochron methods may produce different ages. In Section 3, we noted that there is a good agreement (within uncertainties) between the mean U-Th ages calculated with the different methods, but that isochron uncertainties are often larger than the STRUTages uncertainties. It can be related to the data scattering around the calculated isochron, which is quantified by the Mean Square of Weighted Deviates, or MSWD (Ludwig, 2006). MSWD values >> 1 indicate more scatter 
1 than predicted by the analytical errors. Values $\leq 1$ correspond to a good fit of the data by the

2 isochron. Looking at the examples given in Section 3, it appears that: -when MSWD < 1 (e.g. subsamples 1\#1-3 of the Santo coral core and Rupt du Puits speleothem), both methods give similar uncertainties. In this case, the different subsamples plot on the isochrons with a well-defined $\mathrm{R}_{\mathrm{i}}$ value. The age uncertainty corresponds to the analytical scattering and there is no additional uncertainty such as $\mathrm{R}_{\mathrm{i}}$ variability due to multiple detrital components. In this favorable case, STRUTages and Isoplot should give similar results, as it is the case for the subsamples $1 \# a, b, c$ of the Santo coral . In the Rupt du Puits case, the ages given by STRUTages $(\approx 5.3 \pm 0.4 \mathrm{ka})$ and I soplot largely overlap $(5.6 \pm 0.7 \mathrm{ka})$ but the mean age of STRUTages is about $0.3 \mathrm{ka}$ older than the mean Isoplot age. This is because $R_{i}(=0.2 \pm 0.6)$ is poorly defined by Isoplot (there is small range in ${ }^{232} \mathrm{Th} /{ }^{238} \mathrm{U}$ between the three coeval sub-samples, see Table ES2) and it includes negative values with no physical reality (but that may correspond to an open-system behavior). Conversely, STRUTages simulates only positive $R_{i}$ values $\left(R_{i}=0.36+0.37 /\right.$ 0.24). As a consequence, STRUTagescalculates larger initial ${ }^{230} \mathrm{Th}$ corrections and lower mean ages than Isoplot.

- when MSWD > 1 (Santa Elina, subsamples 1\#1-4 of the Santo coral core), the samples are scattered around the isochron: the fit is poor. Isoplot propagates this scattering into to the age uncertainty, whereas STRUTages minimizes this scattering by adjusting the $\mathrm{R}_{\mathrm{i}}$ of each sample to obtain a common age for the whole subsample set. Hence, for large MSWD values, the different hypothesis of Isoplot and STRUTages lead to different uncertainties. Therefore checking the validity of these hypotheses will be crucial for STRUTages (see Section 4.2.). 
$1 \quad 4.2$ Combining stratigraphical and strict coevality constraints

The stratigraphical constraints method is presented as possibly more appropriate to correct of speleothem samples for detrital contamination than isochron because it explicitly assumes that the detrital Th is of variable isotopic composition, whereas isochron techniques assumes a homogeneous detrital end-member that may not be representative of the whole speleothem (Hellstrom, 2006). Why then do we introduce strict coevality constraints with STRUTages? While STRUTages calculates $\mathrm{R}_{\mathrm{i}}$ ranges that bring coeval sub-samples within the same age range, it does not directly use these $R_{i}$ values to correct for the initial thorium of the samples collected on other stratigraphical level like one would do with an isochron. Instead, STRUTages selects for each sample the range of $R_{i}$ that is most likely to fulfill both coevality and stratigraphic constraints. It influences the non-coeval sample ages because:

- The restricted age range of coeval samples puts an upper limit on the possible ages of younger samples and a lower limit on the possible ages of older samples) - the $\mathrm{R}_{\mathrm{i}}$ range imposed by strict coevality constraints may restrict the range of possible $R_{i}$ of the whole sample set or require high $\Delta R_{i}$ to fulfill all the constraints simultaneously.

When the $\mathrm{R}_{\mathrm{i}}$ ranges of all the samples have a common intersection (this is the case for Santa Elina and Rupt du Puits), any $\mathrm{R}_{\mathrm{i}}$ value in this intersection can be used to correct the initial Th content of all the samples and will leave them in the stratigraphical order. Conversely, when the intersection of all the $R_{i}$ ranges is null, a certain range of variability $\left(\Delta \mathrm{R}_{\mathrm{i}}\right)$ is required leave all the samples in the stratigraphical order (Santo coral core with strong constraints). These two types of behavior were extensively discussed for the stratigraphical method without coevality constraints (Hellstrom, 2006, Pons-Branchu et al., 2014). 
1

The Santa Elina and the Rupt du Puits speleothems are two extreme cases of the relative weight of stratigraphical and strict coeval samples:

- For Santa Elina, most of the constraint on $\mathrm{R}_{\mathrm{i}}$ come from the strict coevality constraints on the 3 coeval subsamples. This is reflected by the significant decrease of the uncertainties on ages and $R_{i}$ when the strict coevality constraints are included (Figure 2) and to the similar age and $R_{i}$ ranges obtained for the three SE-top samples alone or with SE 43-46 and SE 78-83 (Table 2, with strict coevality constraints).

- By contrast, in the Rupt du Puits speleothem, most constraints come from the stratigraphical constraints on the non-coeval samples due to the large range in ${ }^{232} \mathrm{Th} /{ }^{238} \mathrm{U}$ (up to a factor 50 ) ratio along the speleothem (see electronic supplement, Table ES2). This is reflected in the similar uncertainties on ages and $\mathrm{R}_{\mathrm{i}}$ with or without strict coevality constraints (Fig. 3b). As a consequence, the ages of the 3 subsamples (R69-6abc) are much better defined by the weak constraints applied to the whole speleothem than by the strict constraints on coeval samples alone (Tab. 3). The impact of the strong constraints on coeval samples is restricted to a $10 \%$ decrease of the uncertainties, when the strong constraints on coeval samples are applied to the whole speleothem.

The two previous examples illustrate the interplay between the different constraints used in the model. However, they do not guarantee the validity of the modeled ages.

For the Santa Elina speleothem, there is a significant disagreement between the ages obtained with the loose and strict coevality constrains and the ${ }^{14} \mathrm{C}$ ages that are all less than 550 a. This may be due to: 
1- U-Th ages can be overestimated compared to ${ }^{14} \mathrm{C}$ ages in case of $\mathrm{U}$ loss (Plagnes et al. 2003). This is possible considering that the Santa Elina speleothem grows in a rock shelter. Alternatively, ${ }^{14} \mathrm{C}$-rich young organic matter can contaminate carbonates but it usually concerns old carbonates (Holmgren et al., 1994; Goslar et al., 2000).

2- The $\left({ }^{230} \mathrm{Th} /{ }^{232} \mathrm{Th}\right)_{A}$ ratios of the Santa Elina samples range from 0.6 to 1.9 , within the range of possible values for the $\left({ }^{230} \mathrm{Th} /{ }^{232} \mathrm{Th}\right)_{A O}$ ratio. So, it is possible that the Santa Elina speleothem is very young (550 a or less) so that $\left({ }^{230} \mathrm{Th} /{ }^{232} \mathrm{Th}\right)_{A 0} \approx$ $\left({ }^{230} \mathrm{Th} /{ }^{232} \mathrm{Th}\right)_{A}$ and that $\left({ }^{230} \mathrm{Th} /{ }^{232} \mathrm{Th}\right)_{A}$ variations just reflect $\left({ }^{230} \mathrm{Th} /{ }^{232} \mathrm{Th}\right)_{A O}$ variations. In this case, there is no discrepancy between the U-Th and the ${ }^{14} \mathrm{C}$ ages (remember that the ${ }^{14} \mathrm{C}$ ages are not corrected for the dead carbon).

It is beyond the scope of this article to choose between these two hypotheses. However it highlights two important methodological implications:

1) If the U-Th behaves as an open system, STRUTages ages are meaningless.

2) Whatever the real ages are, a trivial solution is that all Santa Elina U-Th ages are equal to zero if $\left({ }^{230} \mathrm{Th} /{ }^{232} \mathrm{Th}\right)_{A O} \approx\left({ }^{230} \mathrm{Th} /{ }^{232} \mathrm{Th}\right)_{A}$. However STRUTages does not find this solution. One reason is that the exponential distribution used to randomized $\mathrm{R}_{\mathrm{i} \_ \text {mean }}$ favor low $\mathrm{R}_{\mathrm{i} \_ \text {mean }}$ values (and thus large ages). Thus trials with $\mathrm{R}_{\mathrm{i}} \approx 0.35$ are more likely to be appear than trials with $\mathrm{R}_{\mathrm{i}} \approx 1.6-1.9$ necessary to set the ages of samples SE $43-46 \mathrm{~mm} / \mathrm{top}$ and SE $78-83 \mathrm{~mm} /$ top close to zero.

Even if the zero age solution is statistically less probable than the one proposed by STRUTages, it does not mean that it is the correct one. In such a case with $\left({ }^{230} \mathrm{Th} /{ }^{232} \mathrm{Th}\right)_{\mathrm{A}}$ ratios in the range permitted for $\left({ }^{230} \mathrm{Th}^{232} \mathrm{Th}\right)_{\mathrm{A} 0}$ and with high 
1

2

3

4

5

6

7

8

9

10

11

$\left({ }^{232} \mathrm{Th} /{ }^{238} \mathrm{U}\right)_{\mathrm{A}}$, ratios geochemical arguments or absolute dating are required to determine the correct age.

The Santo coral core provides the opportunity to compare modeled age with true ages obtained by growth band counting on a coral in which variations of the initial $\left({ }^{230} \mathrm{Th} /{ }^{232} \mathrm{Th}\right)_{\mathrm{A}}$ activity ratio are clearly documented. The good agreement (within uncertainties) between the modelled and the counted ages gives confidence (at least in this example) to the reliability of the STRUTages method. The uncertainties on the ages modeled with STRUTages are generally larger than those obtained with isochrons by Shen et al. (2008). However, two points must be noted:

- the good agreement between the U-Th ages of Shen et al. (2008) and counted ages for samples $3,4,5$ and 6 is due to the choice of a $R_{i}$ of 1 (isochron 1) rather than 4.5 (isochron 2) for these samples. This choice was obviously influenced by the known counted ages. However, generally carbonates are dated by the U-Th method because no counted age is available.

- To be self-consistent in their approach, Shen and coworkers apply a $\mathrm{R}_{\mathrm{i}}$ ratio of 1.0 to sample $1 \# \mathrm{~d}$ and hence significantly overestimate its age.

Hence, STRUTages combines efficiently the stratigraphical constraints of Hellstrom (2006) and the constraints on coeval samples that are traditionally treated by isochrons.

One of the sources of uncertainty with the stratigraphical constraint model is the maximum value of $\Delta R_{i}$ (the variability of the $R_{i}$ ratio within the speleothem) that should be used to evaluate the ages and their uncertainties. In some cases, the variability of $R_{i}$ is well established in corals (Shen et al, 2008) or in speleothems (Dorale et al., 2004). However, there 
1 is a risk that a need of using large values of $\Delta R_{i}$ to set samples in stratigraphical order

2 corresponds to an open system problem (Hellstrom, 2006). While the stratigraphic model does

3 not favor a particular $\Delta \mathrm{R}_{\mathrm{i}}$ value, the few studies using the stratigraphical constraint methods

4 have used $\Delta \mathrm{R}_{\mathrm{i}}$ values on the low side of the possible range (Hellstrom, 2006, Pons-Branchu et

5 al., 2014). It has the advantage of reducing the uncertainties on the modelled ages but may

6 lead to an underestimation of these uncertainties. The problem is that at present only too few

7 studies focus on the variability of the $\left({ }^{230} \mathrm{Th} /{ }^{232} \mathrm{Th}\right)_{\mathrm{A}}$ activity ratio of detrital material in

8 speleothems (Beck et al., 2001, Carolin et al. 2013, Labonne et al., 2002, Meyer et al., 2012,

9 Richards and Dorale, 2003, Yuan et al., 2004, Moseley et al., 2014) or corals (Shen et al.,

2008). Seawater is used to determine the $\left({ }^{230} \mathrm{Th} /{ }^{232} \mathrm{Th}\right)_{\mathrm{A} 0}$ activity ratio of corals (Shen et al.,

2008). However, the residence time of Th is very short (1 year at most) in the surface ocean so that the $\left({ }^{230} \mathrm{Th} /{ }^{232} \mathrm{Th}\right)_{\mathrm{A}}$ activity ratio of seawater may significantly evolve through time.

More studies are needed to have a better view of the variability of $R_{i}$ in speleothems and corals.

STRUTages adjusts the $R_{i}$ of each coeval subsample of a given stratigraphical level to obtain the same age for each subsample. Unlike the isochron method, it does not consider the possibility for open system behavior. In general, speleothems develop in protected environments, so that open system behaviors are rare. When it occurs, it can be detected by mineralogical studies (Borsato et al, 2003, Scholz et al., 2014). In corals, the detection of calcite in aragonitic coral species is a strong indication of open system behavior. The ${ }^{234} \mathrm{U} /{ }^{238} \mathrm{U}$ initial ratio in corals is also used as a clue for open or closed system behavior, as this ratio is expected to display small variations over the past climatic cycles (Robinson et al., 2006). However, some diagenetic alterations could be not detected by these means and further geochemical analyses could be necessary (Bar-Matthews et al., 1993; Pons-Branchu et al., 2005). If, for a given speleothem, the range of the $\left({ }^{230} \mathrm{Th} /{ }^{232} \mathrm{Th}\right)$ activity ratio of the potential 
1 detrital thorium sources is known, STRUTages is well suited to propagate the corresponding

2 uncertainties.

3

4

5

6

7

8

9

10

11

\section{Conclusion}

The combination of the stratigraphical constraints proposed by Hellstrom (2006) together with the strict coevality constraints proposed here provides a robust way to constraints the initial $\left({ }^{230} \mathrm{Th} /{ }^{232} \mathrm{Th}\right)$ activity ratio of stratified carbonates. Compared to the isochron method it has the advantage of not requiring the assumption of a single $\left({ }^{230} \mathrm{Th} /{ }^{232} \mathrm{Th}\right)_{\mathrm{A} 0}$ initial activity ratio value and to allow the change of this ratio along the speleothem/coral or within a stratigraphical horizon. From that respect, the strict coevality constraints provide an alternative to isochrons to calculate the age of samples with less restrictive assumption. The field of application of this method is not restricted to carbonate dating. It could be useful for U-Th dating of Quaternary-aged lava flow sequences and may be also applicable to other isotopic systems with initial isotope heterogeneities.

\section{Acknowledgements:}

Many thanks to Michel Fontugne for his kind permission to use the Santa Elina data. We are grateful to Ken Ludwig for his prompt answers to our questions on Isoplot. We thank David Richards and an anonymous reviewer for their constructive comments. This project was supported by the "Paris 2030" and Ec2CO programs by grants to E P-B. This is LSCE contribution number 5582. 


\section{References}

3

4

Albarède, F., 1995. Introduction to Geochemical Modeling. Cambridge University Press, Cambridge.

Allègre, C. J., 2008. Isotope geology. Cambridge University Press, Cambridge.

Bar-Matthews M., Wasserburg G.J., Chen J.H.,1993. Diagenesis of fossil coral skeletons: Correlation between trace elements, textures, and ${ }^{234} \mathrm{U} /{ }^{238} \mathrm{U}$. Geochimica et Cosmochimica Acta, 57, 257-276.

Beck, J.W., Richards, D.A., Edwards, R.L., Silverman, B.W., Smart, P.L., Donahue, D.J., 0 Hererra-Osterheld, S., Burr, G.S., Calsoyas, L., Jull, A.J.T., Biddulph, D., 2001. Extremely 1 large variations of atmospheric C-14 concentration during the last glacial period. Science $292,2453-2458$.

Bischoff J. L. and Fitzpatrick J. A., U-series dating of impure carbonates: an isochron technique using total-sample dissolution. Geochim. Cosmochim. Acta 55, 1991, 543-554.

Borsato, A., Quinif, Y., Bini, A., \& Dublyansky, Y., 2003. Open-system alpine speleothems: implications for U-series dating and paleoclimate reconstructions. Studi Trent. Sci. Nat., Acta Geol. 80, 71-83.

Carolin, S. A., Cobb, K. M., Adkins, J. F., Clark, B., Conroy, J. L., Lejau, S., ... \& Tuen, A. 9 A., 2013. Varied response of western Pacific hydrology to climate forcings over the last glacial period. Science 340, 1564-1566. 
1 Dorale, J.A., Edwards, R. L., Alexander Jr, E.C., Shen, C.C., Richards, D. A., \& Cheng, H., 2 2004. Uranium-series dating of speleothems: current techniques, limits \& applications. In 3 Studies of Cave Sediments (pp. 177-197). Springer US.

4 Ersek, V, Hostetler, S.W., Cheng, H., Clark, P.U., Anslow, F.S., Mix, A.C., Edwards, R.L., 5 2009. Environmental influences on speleothem growth in southwestern Oregon during the last 380000 years. Earth Planet. Sci. Lett., 279 (3-4), 316-325.

Geyh, M., 2008. Selection of suitable data sets improves $230 \mathrm{Th} / \mathrm{U}$ dates of dirty material. Geochronometria, 30, 69-77.

Goslar T, Hercman H, Pazdur A, 2000. Comparison of U-series and radiocarbon dates of speleothems. Radiocarbon 42, 403-414.

Hellstrom, J., 2006. U-Th dating of speleothems with high initial ${ }^{230}$ Th using stratigraphical constraints. Quat. Geochronol. 1, 289-295.

Holmgren K, Lauritzen SE, Possnert G. 1994. 230Th/234U dating of a Late Pleisto cene stalagmite in Lobatse II Cave, Botswana. Quaternary Science Reviews 13,: 111 - 9

Hu, C.-Y., Henderson, G.M., Huang, J.-H., Xie, S.-C., Sun, Y., Johnson, K.R., 2008. Quantification of Holocene Asian monsoon rainfall from spatially separated cave records. Earth and Planetary Science Letters 266, 221-232.

Jaillet, S., Pons-Branchu, E., Maire, R., Hamelin, B. \& Brulhet, J., 2006. Record of Holocene palaeo-groundwater floods in two stalagmites of the Rupt-Du-Puits Sytem (Barrois, France). Morphological analysis of laminae and U/Th TIMS datings. Geologica Belgica, 9, 297-307. 
1 Labonne, M., Hillaire-Marcel, C., Ghaleb, B., \& Goy, J.L., 2002. Multi-isotopic age

2 assessment of dirty speleothem calcite: an example from Altamira Cave, Spain. Quaternary

3 science reviews, 21, 1099-1110.

4 Ludwig, K.R., 2003. Mathematical-statistical treatment of data and errors for Th-230/U

5 geochronology. Reviews in Mineralogy \& Geochemistry 52, 631-656.

6 Ludwig K.R., Titterington, D.M., 1994. Calculation of 230Th/U Isochrons, ages, and errors:

7 Geochim Cosmochim Acta 58, 5031-5042.

Marchandise, S., Robin, E., Ayrault, S., and Roy-Barman, M., 2014. U-Th-REE-Hf bearing phases in Mediterranean Sea sediments: Implications for isotope systematics in the ocean. Geochimica et Cosmochimica Acta, 131, 47-61.

Meyer, M. C., Spötl, C., Mangini, A., \& Tessadri, R., 2012. Speleothem deposition at the glaciation threshold-An attempt to constraint the age and paleoenvironmental significance of a detrital-rich flowstone sequence from Entrische Kirche Cave (Austria). Palaeogeography, Palaeoclimatology, Palaeoecology, 319, 93-106.

Moseley G.E., Spötl C., Svensson A., Cheng H., Brandstätter S. and Edwards, L., 2014. Multi-speleothem record reveals tightly coupled climate between central Europe and Greenland during Marine Isotope Stage 3. Geology 42;1043-1046

Plagnes, V., Causse, C., Fontugne, M., Valladas, H., Chazine, J. M. and Fage, L. H., 2003. Cross dating (Th/U-14 C) of calcite covering prehistoric paintings in Borneo. Quaternary Research, 60, 172-179.

Pons-Branchu, E., 2001. Datation haute résolution de spéléothèmes $\left({ }^{230} \mathrm{Th} /{ }^{234} \mathrm{U}\right.$ et $\left.{ }^{226} \mathrm{Ra} /{ }^{238} \mathrm{U}\right)$. Application aux reconstitutions environnementales autour des sites du Gard et de Meuse / Haute-Marne. Thesis. Univ. Aix-Marseille, 190 p. 
1 Pons-Branchu, E., Douville, E., Roy-Barman, M., Dumont, E., Branchu, P., Thil, F., Frank,

2 N., Bordier, L. and Borst, W., 2014. A geochemical perspective on Parisian urban history

3 based on U-Th dating, laminae counting and yttrium and REE concentrations of recent

4 carbonates in underground aqueducts. Quaternary Geochronology 24, 44-53.

5 Pons-Branchu, E., Hillaire-Marcel, C., Deschamps, P., Ghaleb, B. and Sinclair, D. J., 2005.

6 Early diagenesis impact on precise U-series dating of deep-sea corals: Example of a 100

7 200-years old Lophelia pertusa sample from the northeast Atlantic. Geochimica et

8 Cosmochimica Acta, 69, 4865-4879.

Quarteroni, A. and Saleri, F., 2006. Scientific Computing with MATLAB and Octave, vol. 2 of Texts in Computational Science and Engineering. Springer-Verlag, Berlin Heidelberg.

Richards, D. A., \& Dorale, J. A., 2003. Uranium-series chronology and environmental applications of speleothems. Reviews in Mineralogy and Geochemistry 52, 407-460.

Robinson, L.F., Adkins, J.F., Fernandez, D.P., Burnett, D.S., Wang, S.L., Gagnon, A.C. and Krakauer, N., 2006. Primary U distribution in scleractinian corals and its implications for U series dating. Geochemistry, Geophysics, Geosystems 7, 1-20, doi:10.1029/2005GC001138. Q05022.

Scholz, D., Tolzmann, J., Hoffmann, D. L., Jochum, K. P., Spötl, C., \& Riechelmann, D. F. 2014. Diagenesis of speleothems and its effect on the accuracy of ${ }^{230} \mathrm{Th} / \mathrm{U}$-ages. Chemical Geology, 387, 74-86.

Shen, C. C., Li, K. S., Sieh, K., Natawidjaja, D., Cheng, H., Wang, X., and Kilbourne, K. H., 2008. Variation of initial ${ }^{230} \mathrm{Th} /{ }^{232} \mathrm{Th}$ and limits of high precision U-Th dating of shallowwater corals. Geochimica et Cosmochimica Acta, 72(17), 4201-4223. 
1 Wortham, B.E., Banner, J.L., James, E. and Loewy, S.L., 2013. Direct Measurement of Initial $2{ }^{230} \mathrm{Th} /{ }^{232} \mathrm{Th}$ Ratios in Central Texas Speleothems for More Accurate Age Determination.

3 American Geophysical Union, Fall Meeting 2013, abstract \#V13A-2595

4 Yuan, D.X., Cheng, H., Edwards, R.L., Dykoski, C.A., Kelly, M.J., Zhang, M.L., Qing, J.M., 5 Lin, Y.S., Wang, Y.J., Wu, J.Y., Dorale, J.A., An, Z.S., Cai, Y.J., 2004. Timing, duration, 6 and transitions of the Last Interglacial Asian Monsoon. Science 304, 575-578.

7

8

9

10

11

12

13 
2 Table 1: STRUTages-Isoplot comparison for selected synthetic samples.

\begin{tabular}{|l|c|c|c|c|}
\hline & $\left(\begin{array}{c}{ }^{230} \mathrm{Th} /{ }^{238} \mathrm{U}_{\mathrm{A}}{ }^{*} \\
2 \sigma^{* *}\end{array}\right.$ & $\begin{array}{c}\left.{ }^{234} \mathrm{U} /{ }^{238} \mathrm{U}\right)_{\mathrm{A}} \\
2 \sigma^{* *}\end{array}$ & $\begin{array}{c}\text { Is oplot } \\
\text { age }(\mathrm{ka}) \\
+/-^{* * *}\end{array}$ & $\begin{array}{c}\text { STRUTages } \\
\text { age }(\mathrm{ka}) \\
+/-^{* * *}\end{array}$ \\
\hline$\approx 330$ ka old sample & 1.130 & 1.140 & 331 & 332 \\
& $\pm 0.6 \%$ & $\pm 0.5 \%$ & $+17 /-15$ & $+14 /-13$ \\
\hline sample on the infinite age line & 1.65 & 1.43 & 552 & 569 \\
& $\pm 5 \%$ & $\pm 4 \%$ & $+370 /-200$ & $+321 /-191$ \\
\hline
\end{tabular}
value). 
Published in Quaternary Geochronology, Volume 32, April 2016, Pages 29-39

1 
Table 2: Simulation results for the Santa Elina speleothem.

\begin{tabular}{|c|c|c|c|c|c|c|c|c|}
\hline & \multicolumn{2}{|c|}{ Weak constraints } & \multicolumn{2}{|c|}{$\begin{array}{l}\text { Strong constraints } \\
\text { (all samples) }\end{array}$} & \multicolumn{2}{|c|}{$\begin{array}{l}\text { strong constraints } \\
\text { (3 subsamples only) }\end{array}$} & \multicolumn{2}{|c|}{$\begin{array}{l}\text { Isoplot isochron } \\
\text { (3 subsamples only) }\end{array}$} \\
\hline & $\begin{array}{l}\text { mean age } \\
+/-(\mathrm{ka})\end{array}$ & $\begin{array}{l}\mathrm{R}_{\mathrm{i}} \\
+/-(\mathrm{AR})\end{array}$ & $\begin{array}{l}\text { mean age } \\
+/-(\mathrm{ka})\end{array}$ & $\begin{array}{l}\mathrm{R}_{\mathrm{i}} \\
+/-(\mathrm{AR})\end{array}$ & $\begin{array}{l}\text { mean age } \\
+/-(\mathrm{ka})\end{array}$ & $\begin{array}{l}\mathrm{R}_{\mathrm{i}} \\
+/-(\mathrm{AR})\end{array}$ & $\begin{array}{l}\text { mean age } \pm \\
2 \sigma(\mathrm{ka})\end{array}$ & $\begin{array}{l}\mathrm{R}_{\mathrm{i}}+/- \\
(\mathrm{AR})\end{array}$ \\
\hline SE Top B & $\begin{array}{l}2.3 \\
+1.6 /-1.6\end{array}$ & $\begin{array}{l}0.35 \\
+0.24 /-0.23\end{array}$ & $\begin{array}{l}2.39 \\
+0.17 /-0.18\end{array}$ & $\begin{array}{l}0.34 \\
+0.3 /-0.3\end{array}$ & $\begin{array}{l}2.39 \\
+0.17 /-0.18\end{array}$ & $\begin{array}{l}0.34 \\
+0.3 /-0.3\end{array}$ & $2.3 \pm 2.5$ & $0.35 \pm 0.41$ \\
\hline SE Top C & $\begin{array}{l}2.2 \\
+1.8 /-1.9\end{array}$ & $\begin{array}{l}0.35 \\
+0.24 /-0.23\end{array}$ & $\begin{array}{l}2.36 \\
+0.18 /-0.17\end{array}$ & $\begin{array}{l}0.34 \\
+0.3 /-0.3\end{array}$ & $\begin{array}{l}2.36 \\
+0.18 /-0.17\end{array}$ & $\begin{array}{l}0.34 \\
+0.3 /-0.3\end{array}$ & \multirow{2}{*}{\multicolumn{2}{|c|}{$\mathrm{MSDW}=25$}} \\
\hline SE-Top D & $\begin{array}{l}2.2 \\
+1.1 /-1.2\end{array}$ & $\begin{array}{l}0.35 \\
+0.24 /-0.23\end{array}$ & $\begin{array}{l}2.37 \\
+0.15 /-0.15\end{array}$ & $\begin{array}{l}0.34 \\
+0.3 /-0.3\end{array}$ & $\begin{array}{l}2.37 \\
+0.15 /-0.15\end{array}$ & $\begin{array}{l}0.34 \\
+0.3 /-0.3\end{array}$ & & \\
\hline $\begin{array}{l}\mathrm{SE} 43-46 \\
\mathrm{~mm} / \mathrm{top}\end{array}$ & $\begin{array}{l}5.4 \\
+0.9 /-0.9\end{array}$ & $\begin{array}{l}0.35 \\
+0.24 /-0.23\end{array}$ & $\begin{array}{l}5.61 \\
+0.47 /-0.47\end{array}$ & $\begin{array}{l}0.34 \\
+0.3 /-0.3\end{array}$ & & & & \\
\hline $\begin{array}{l}\text { SE 78-83 } \\
\text { mm/top }\end{array}$ & $\begin{array}{l}7.7 \\
+1.5 /-1.6\end{array}$ & $\begin{array}{l}0.35 \\
+0.24 /-0.23\end{array}$ & $\begin{array}{l}8.17 \\
+0.60 /-0.60\end{array}$ & $\begin{array}{l}0.34 \\
+0.3 /-0.3\end{array}$ & & & & \\
\hline
\end{tabular}


Table 3: Simulation results for the Rupt du Puits speleothem.

\begin{tabular}{|c|c|c|c|c|c|c|c|c|}
\hline & \multicolumn{2}{|c|}{ Weak constraints } & \multicolumn{2}{|c|}{$\begin{array}{l}\text { Strong constraints } \\
\text { (all samples) }\end{array}$} & \multicolumn{2}{|c|}{$\begin{array}{l}\text { strong constraints } \\
\text { (3 subsamples only) }\end{array}$} & \multicolumn{2}{|c|}{$\begin{array}{l}\text { Isoplot isochron } \\
\text { (3subsamples only) }\end{array}$} \\
\hline & $\begin{array}{l}\text { mean age } \\
+/-(\mathrm{ka})\end{array}$ & $\begin{array}{l}\mathrm{R}_{\mathrm{i}} \\
+/-(\mathrm{AR})\end{array}$ & $\begin{array}{l}\text { mean age } \\
+/-(\mathrm{ka})\end{array}$ & $\begin{array}{l}\mathrm{R}_{\mathrm{i}} \\
+/-(\mathrm{AR})\end{array}$ & $\begin{array}{l}\text { mean age } \\
+/-(\mathrm{ka})\end{array}$ & $\begin{array}{l}\mathrm{R}_{\mathrm{i}} \\
+/-(\mathrm{AR})\end{array}$ & $\begin{array}{l}\text { mean age } \\
\pm 2 \sigma(\mathrm{ka})\end{array}$ & $\begin{array}{l}\mathrm{R}_{\mathrm{i}}+/- \\
(\mathrm{AR})\end{array}$ \\
\hline R69-1 & $\begin{array}{r}4.12 \\
+0.31 /-0.55 \\
\end{array}$ & $\begin{array}{c}0.77 \\
+0.12 /-0.11 \\
\end{array}$ & $\begin{array}{r}4.16 \\
+0.27 /-0.46 \\
\end{array}$ & $\begin{array}{c}0.76 \\
+0.09 /-0.08 \\
\end{array}$ & & & & \\
\hline R69-3 & $\begin{array}{r}4.45 \\
+0.05 /-0.04\end{array}$ & $\begin{array}{c}0.77 \\
+0.12 /-0.11\end{array}$ & $\begin{array}{r}4.45 \\
+0.04 /-0.04\end{array}$ & $\begin{array}{c}0.76 \\
+0.09 /-0.08\end{array}$ & & & & \\
\hline R69-4 & $\begin{array}{r}4.74 \\
+0.10 /-0.10\end{array}$ & $\begin{array}{c}0.77 \\
+0.12 /-0.11\end{array}$ & $\begin{array}{r}4.75 \\
+0.09 /-0.09\end{array}$ & $\begin{array}{c}0.76 \\
+0.09 /-0.08\end{array}$ & & & & \\
\hline R69-6a & $\begin{array}{r}4.92 \\
+0.15 /-0.16\end{array}$ & $\begin{array}{c}0.77 \\
+0.12 /-0.11\end{array}$ & $\begin{array}{r}4.92 \\
+0.12 /-0.13\end{array}$ & $\begin{array}{c}0.76 \\
+0.09 /-0.08\end{array}$ & $\begin{array}{c}5.3 \\
+0.3 /-0.4\end{array}$ & $\begin{array}{c}0.36 \\
+0.37 /-0.24\end{array}$ & $5.6 \pm 0.7$ & $0.2 \pm 0.6$ \\
\hline R69-6b & $\begin{array}{r}4.81 \\
+0.13 /-0.12\end{array}$ & $\begin{array}{c}0.77 \\
+0.12 /-0.11\end{array}$ & $\begin{array}{r}4.82 \\
+0.12 /-0.11\end{array}$ & $\begin{array}{c}0.76 \\
+0.09 /-0.08\end{array}$ & $\begin{array}{c}5.2 \\
+0.3 /-0.4\end{array}$ & $\begin{array}{c}0.36 \\
+0.37 /-0.24\end{array}$ & & \\
\hline R69-6c & $\begin{array}{r}4.94 \\
+0.14 /-0.15\end{array}$ & $\begin{array}{c}0.77 \\
+0.12 /-0.11\end{array}$ & $\begin{array}{r}4.93 \\
+0.12 /-0.13\end{array}$ & $\begin{array}{c}0.76 \\
+0.09 /-0.08\end{array}$ & $\begin{array}{c}5.3 \\
+0.3 /-0.4\end{array}$ & $\begin{array}{c}0.36 \\
+0.37 /-0.24\end{array}$ & MSV & $=0.05$ \\
\hline R69-7 & $\begin{array}{r}5.09 \\
+0.10 /-0.10 \\
\end{array}$ & $\begin{array}{c}0.77 \\
+0.12 /-0.11 \\
\end{array}$ & $\begin{array}{r}5.09 \\
+0.10 /-0.10\end{array}$ & $\begin{array}{c}0.76 \\
+0.09 /-0.08\end{array}$ & & & & \\
\hline R69-9 & $\begin{array}{r}5.37 \\
+0.07 /-0.08\end{array}$ & $\begin{array}{c}0.77 \\
+0.12 /-0.11\end{array}$ & $\begin{array}{r}5.38 \\
+0.07 /-0.07\end{array}$ & $\begin{array}{c}0.76 \\
+0.09 /-0.08\end{array}$ & & & & \\
\hline
\end{tabular}


Table 4: Simulation results for the Santo coral core.

\begin{tabular}{|c|c|c|c|c|c|c|c|c|c|c|c|c|}
\hline & \multicolumn{2}{|c|}{$\begin{array}{l}\text { Weak constraints } \\
\text { (all samples) }\end{array}$} & \multicolumn{2}{|c|}{$\begin{array}{l}\text { Strong constraints } \\
\text { (all samples) }\end{array}$} & \multicolumn{2}{|c|}{$\begin{array}{l}\text { strong constraints } \\
\text { (4 subsamples only) }\end{array}$} & \multicolumn{2}{|c|}{$\begin{array}{l}\text { Isoplot isochron } \\
\text { (4 subsamples only) }\end{array}$} & \multicolumn{2}{|c|}{$\begin{array}{l}\text { strong constraints } \\
\text { (3subsamples only) }\end{array}$} & \multicolumn{2}{|c|}{$\begin{array}{l}\text { Isoplot isochron } \\
\text { (3 subsamples only) }\end{array}$} \\
\hline & $\begin{array}{c}\text { mean age } \\
+/-(\mathrm{a})\end{array}$ & $\begin{array}{c}\mathrm{R}_{\mathrm{i}} \\
+/-(\mathrm{AR})\end{array}$ & $\begin{array}{c}\text { mean age } \\
+/-(\mathrm{a})\end{array}$ & $\begin{array}{c}\mathrm{R}_{\mathrm{i}} \\
+/-(\mathrm{AR})\end{array}$ & $\begin{array}{c}\text { mean age } \\
+/-(\mathrm{a})\end{array}$ & $\begin{array}{c}\mathrm{R}_{\mathrm{i}} \\
+/-(\mathrm{AR})\end{array}$ & $\begin{array}{l}\text { mean age } \\
\pm 2 \sigma \text { (a) }\end{array}$ & $\begin{array}{l}\mathrm{R}_{\mathrm{i}}+/- \\
(\mathrm{AR})\end{array}$ & $\begin{array}{c}\text { mean age } \\
+/- \text { (a) }\end{array}$ & $\begin{array}{c}\mathrm{R}_{\mathrm{i}} \\
+/-(\mathrm{AR})\end{array}$ & $\begin{array}{l}\text { mean age } \\
\pm 2 \sigma(a)\end{array}$ & $\begin{array}{l}\mathrm{R}_{\mathrm{i}}+/- \\
(\mathrm{AR})\end{array}$ \\
\hline $\begin{array}{c}1 \\
\# 1\end{array}$ & $\begin{array}{c}7.6 \\
+5.6 /-6.4\end{array}$ & $\begin{array}{c}2.5 \\
+1.4 /-1.2\end{array}$ & $\begin{array}{r}12.0 \\
+2.6 /-3.2\end{array}$ & $\begin{array}{c}1.5 \\
+0.7 /-0.6\end{array}$ & $\begin{array}{c}10.4 \\
+3.1 /-3.9\end{array}$ & $\begin{array}{c}1.8 \\
+1.2 /-0.9\end{array}$ & \multirow{4}{*}{\multicolumn{2}{|c|}{$15.9 \pm 5.6$}} & $\begin{array}{c}14.2 \\
+1.5 /-1.1\end{array}$ & $\begin{array}{c}1.0 \\
+0.3 /-0.7\end{array}$ & \multirow[b]{2}{*}{$14.2 \pm 1.0$} & \multirow{3}{*}{$1.0 \pm 0.4$} \\
\hline $\begin{array}{c}1 \\
\# 2\end{array}$ & $\begin{array}{c}12.2 \\
+1.8 /-2.2\end{array}$ & $\begin{array}{c}2.6 \\
+1.7 /-1.3\end{array}$ & $\begin{array}{c}12.0 \\
+2.1 /-2.8\end{array}$ & $\begin{array}{c}2.8 \\
+2.4 /-1.6\end{array}$ & $\begin{array}{c}10.5 \\
+3.0 /-3.9\end{array}$ & $\begin{array}{c}3.8 \\
+4.5 /-3.1\end{array}$ & & & $\begin{array}{c}14.1 \\
+0.9 /-0.8\end{array}$ & $\begin{array}{c}1.0 \\
+0.2 /-0.3\end{array}$ & & \\
\hline $\begin{array}{c}1 \\
\# 3\end{array}$ & $\begin{array}{c}12.0 \\
+2.3 /-2.9\end{array}$ & $\begin{array}{c}2.6 \\
+1.7 /-1.3\end{array}$ & $\begin{array}{c}12.2 \\
+2.4 /-3.2\end{array}$ & $\begin{array}{c}2.5 \\
+2.0 /-1.4\end{array}$ & $\begin{array}{c}10.4 \\
+3.1 /-4.0\end{array}$ & $\begin{array}{c}3.4 \\
+3.5 /-2.5\end{array}$ & & & $\begin{array}{c}14.5 \\
+0.8 /-0.9\end{array}$ & $\begin{array}{c}1.0 \\
+0.3 /-0.3\end{array}$ & MSWD $=0.37$ & \\
\hline $\begin{array}{c}1 \\
\# 4\end{array}$ & $\begin{array}{c}15.9 \\
+2.7 /-3.5\end{array}$ & $\begin{array}{c}2.6 \\
+1.7 /-1.3\end{array}$ & $\begin{array}{c}13.1 \\
+2.2 /-3.2\end{array}$ & $\begin{array}{c}4.0 \\
+1.6 /-1.2\end{array}$ & $\begin{array}{c}10.6 \\
+3.1 /-4.1\end{array}$ & $\begin{array}{c}5.1 \\
+3.0 /-2.0\end{array}$ & & & & & & \\
\hline $\begin{array}{c}2 \\
\# 1\end{array}$ & $\begin{array}{c}31.7 \\
+1.6 /-1.9\end{array}$ & $\begin{array}{c}2.6 \\
+1.7 /-1.3\end{array}$ & $\begin{array}{c}31.3 \\
+2.0 /-2.3\end{array}$ & $\begin{array}{c}3.1 \\
+2.1 /-1.8\end{array}$ & $\begin{array}{c}29.4 \\
+0.9 /-1.0\end{array}$ & $\begin{array}{c}4.6 \\
+0.5 /-0.4\end{array}$ & \multirow{4}{*}{$28.7 \pm 2.8$} & \multirow{4}{*}{$4.7 \pm 1.6$} & & & & \\
\hline $\begin{array}{c}2 \\
\# 2\end{array}$ & $\begin{array}{c}31.3 \\
+2.1 /-2.7\end{array}$ & $\begin{array}{c}2.6 \\
+1.7 /-1.3\end{array}$ & $\begin{array}{c}30.9 \\
+2.6 /-2.9\end{array}$ & $\begin{array}{c}2.9 \\
+2.0 /-1.7\end{array}$ & $\begin{array}{c}28.9 \\
+1.0 /-1.0\end{array}$ & $\begin{array}{c}4.6 \\
+0.5 /-0.4\end{array}$ & & & & & & \\
\hline $\begin{array}{c}2 \\
\# 3\end{array}$ & $\begin{array}{c}31.0 \\
+1.9 /-2.3\end{array}$ & $\begin{array}{c}2.6 \\
+1.7 /-1.3\end{array}$ & $\begin{array}{c}30.6 \\
+2.3 /-2.7\end{array}$ & $\begin{array}{c}2.9 \\
+2.1 /-1.7\end{array}$ & $\begin{array}{c}28.9 \\
+1.0 /-1.0\end{array}$ & $\begin{array}{c}4 . \\
+0.5 /-0.4\end{array}$ & & & & & & \\
\hline $\begin{array}{c}2 \\
\# 4\end{array}$ & $\begin{array}{c}34.1 \\
+3.5 /-4.6\end{array}$ & $\begin{array}{c}2.8 \\
+1.7 /-1.3\end{array}$ & $\begin{array}{c}31.4 \\
+2.6 /-3.4\end{array}$ & $\begin{array}{c}3.8 \\
+1.2 /-1.0\end{array}$ & $\begin{array}{c}29.2 \\
+1.1 /-1.2\end{array}$ & $\begin{array}{c}4.6 \\
+0.5 /-0.4\end{array}$ & & & & & & \\
\hline 3 & $\begin{array}{c}36.0 \\
+3.1 /-3.8\end{array}$ & $\begin{array}{c}2.3 \\
+1.5 /-1.2\end{array}$ & $\begin{array}{c}35.8 \\
+3.2 /-3.4\end{array}$ & $\begin{array}{c}2.4 \\
+1.4 /-1.2\end{array}$ & & & & & & & & \\
\hline 4 & $\begin{array}{c}45.8 \\
+0.9 /-1.0\end{array}$ & $\begin{array}{c}2.6 \\
+1.7 /-1.3\end{array}$ & $\begin{array}{c}45.7 \\
+1.0 /-1.1\end{array}$ & $\begin{array}{c}3.0 \\
+2.1 /-1.8\end{array}$ & & & & & & & & \\
\hline 5 & $\begin{array}{c}56.0 \\
+1.7 /-2.2\end{array}$ & $\begin{array}{c}2.6 \\
+1.7 /-1.3\end{array}$ & $\begin{array}{c}55.5 \\
+2.3 /-2.6\end{array}$ & $\begin{array}{c}3.1 \\
+2.2 /-1.8\end{array}$ & & & & & & & & \\
\hline 6 & $\begin{array}{c}65.4 \\
+5.8 /-7.3\end{array}$ & $\begin{array}{c}2.6 \\
+1.6 /-1.3\end{array}$ & $\begin{array}{l}\text { 64. } 2+7.3 /- \\
7.7\end{array}$ & $\begin{array}{c}2.8 \\
+1.7 /-1.6\end{array}$ & & & & & & & & \\
\hline
\end{tabular}


1

2

3 Figure 1: Principle of the stratigraphical and coevality constraints as calculated in

\section{Figure Caption} STRUTages.a: example of valid simulation for a stalagmite without coeval samples. b: example of discarded simulation for a stalagmite without coeval samples. Cases a and b correspond to the Hellstrom (2006) approach with no coeval samples. c: example of valid

simulation with the loose coevality constraints applied to coeval samples. d: example of discarded simulation with the loose coevality constraints applied to coeval samples. e: example of valid simulation with the strict coevality constraints applied to coeval samples. f: example of discarded simulation with the strict coevality constraints applied to coeval samples. Circles and ellipses represent the ages simulated during one trial with the loose coevality constraints. On sub-figures e and f, the small black squares represent the results of the calculated ages used to reconstruct the full error-bar of the sample ages.

Figure 2: Monte Carlo simulation results for the Santa Elina speleothem. a: $\Delta \mathrm{R}_{\mathrm{i}}$ versus $\mathrm{R}_{\mathrm{i} \_ \text {mean }}$ for the successful trails with the loose coevality constraints. b: Age distribution with the loose coevality constraints applied to trials with $\Delta R_{i}<1 \%$. c: $\Delta R_{i}$ versus $R_{i_{-} \text {mean }}$ for the successful trails with the strict coevality constraints. d: Age distribution with the strict coevality constraints applied to trials with $\Delta \mathrm{R}_{\mathrm{i}}<1 \%$ (about 1000 successful trails were obtained by specifically running STRUTages with $\Delta \mathrm{R}_{\mathrm{i}}$ values $<1 \%$ ). Coeval samples are underlined.

Figure 3: Monte Carlo simulation results for the Rupt du Puits speleothem. a: $\Delta R_{i}$ versus $\mathrm{R}_{\mathrm{i} \_ \text {mean }}$ for the successful trails with the loose coevality constraints. b: Age distribution with the loose coevality constraints applied to trials with $\Delta R_{i}<1 \%$. c: $\Delta R_{i}$ versus $R_{i_{-} \text {mean }}$ for the 
1 successful trails with the strict coevality constraints. d: Age distribution with the strict

2 coevality constraints applied to trials with $\Delta \mathrm{R}_{\mathrm{i}}<1 \%$ (about 1000 successful trails were

3 obtained by specifically running STRUTages with $\Delta \mathrm{R}_{\mathrm{i}}$ values $<1 \%$ ). Coeval samples are

4 underlined.

5 Figure 4: Monte Carlo simulation results for the Santo coral core. a: $\Delta R_{i}$ versus $R_{i \_m e a n}$ for

6 the successful trails with the loose coevality constraints. b: Age distribution with the loose

7 coevality constraints applied to trials with $\Delta \mathrm{R}_{\mathrm{i}}<1 \%$. c: $\Delta \mathrm{R}_{\mathrm{i}}$ versus $\mathrm{R}_{\mathrm{i} \_ \text {mean }}$ for the successful

8 trails with the strict coevality constraints. There is no successful trial for $\Delta \mathrm{R}_{\mathrm{i}}<50 \%$. d: Age

9 distribution with the strict coevality constraints applied to trials with $\Delta \mathrm{R}_{\mathrm{i}}<70 \%$. Coeval

10 samples are underlined.

12 Figure 5: Comparison of the calculated ages with the counted ages of the Santo coral. a:

13 STRUTages versus counted ages. b: isochron and isochron-derived ages from Shen et al.

14 (2008) versus counted ages. The continuous line is the 1:1 line. 
Stratigraphical order test
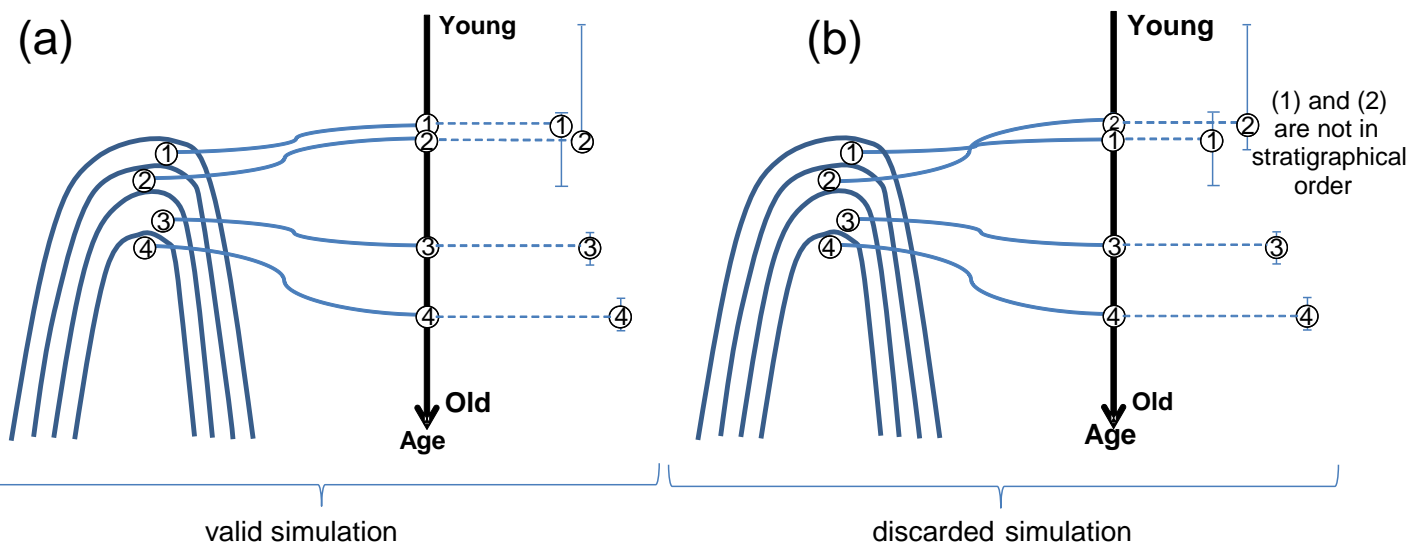

valid simulation

Coeval subsamples : loose coevality constraints
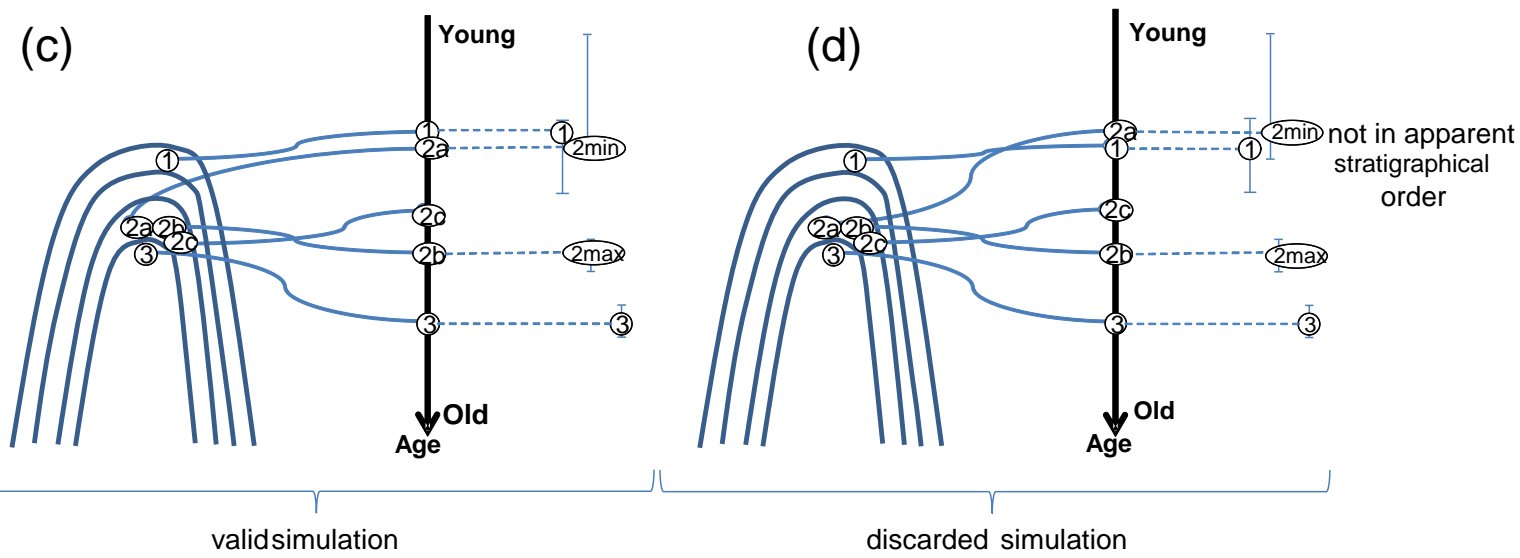

valid simulation

discarded simulation

\section{Coeval subsamples : strict coevality constraints}

(e)

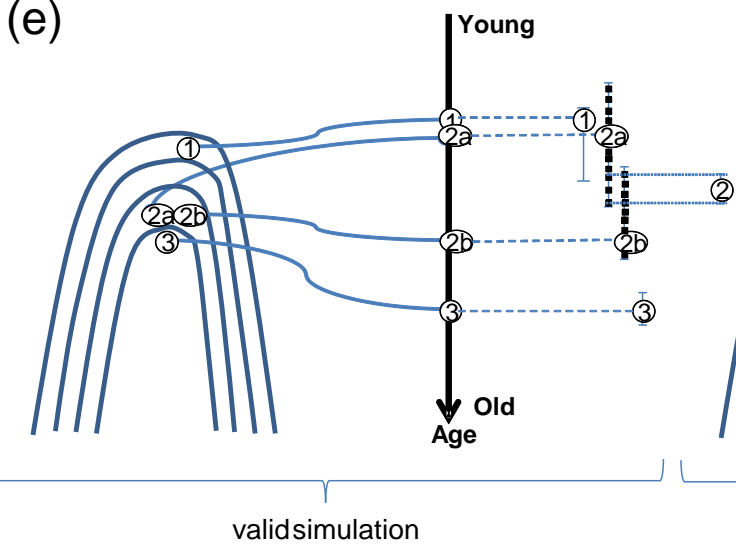

(f)

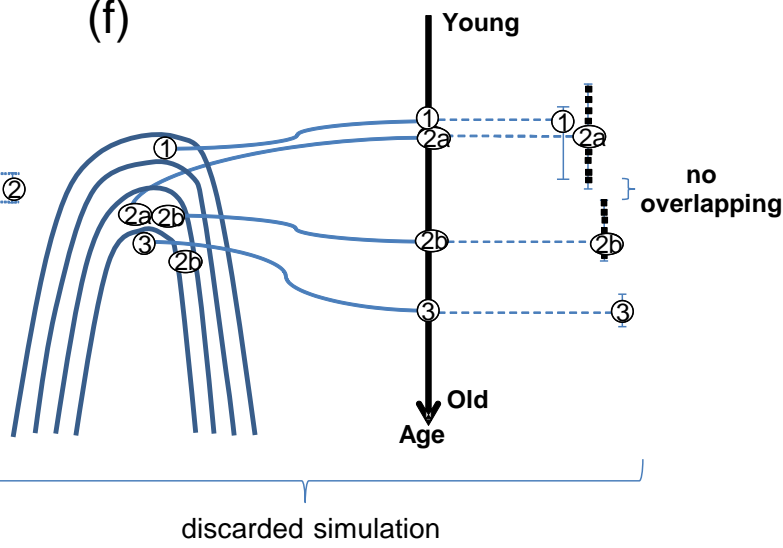

Figure 1 

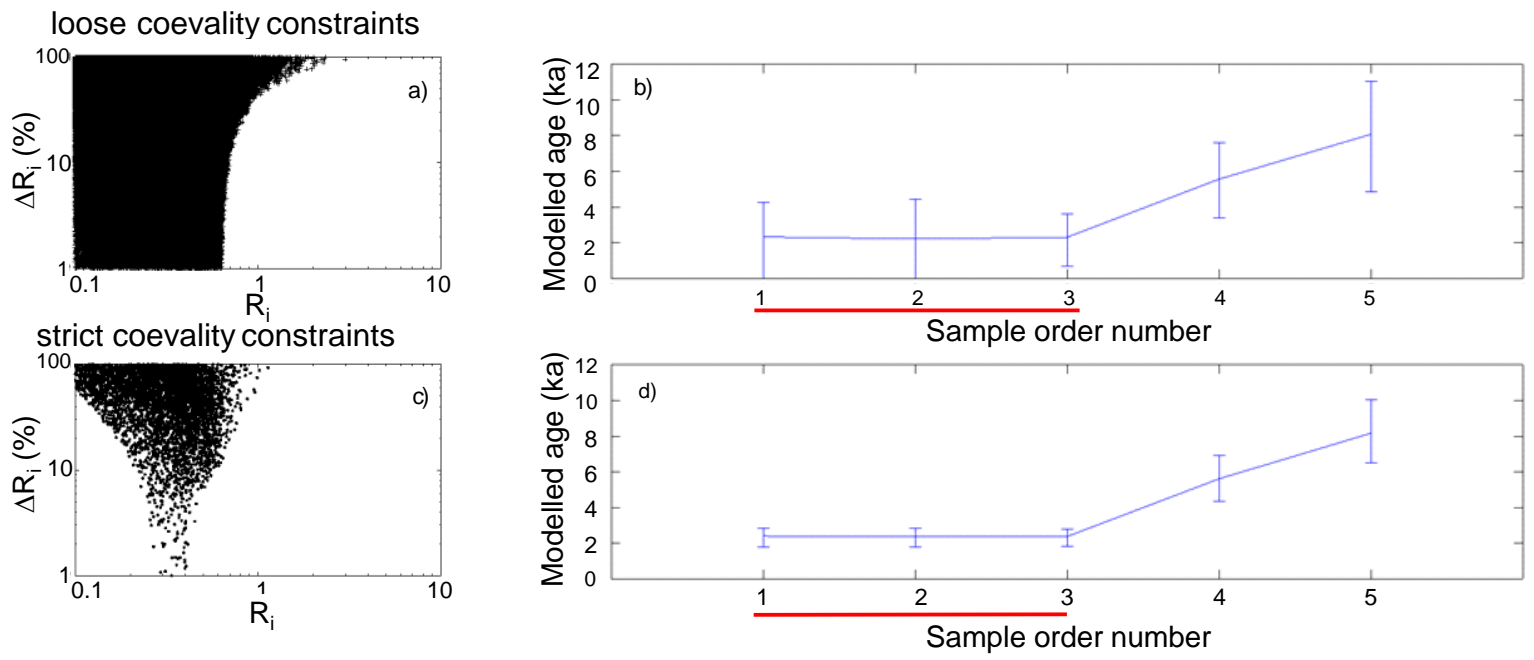

Figure 2 (Santa Elina) 

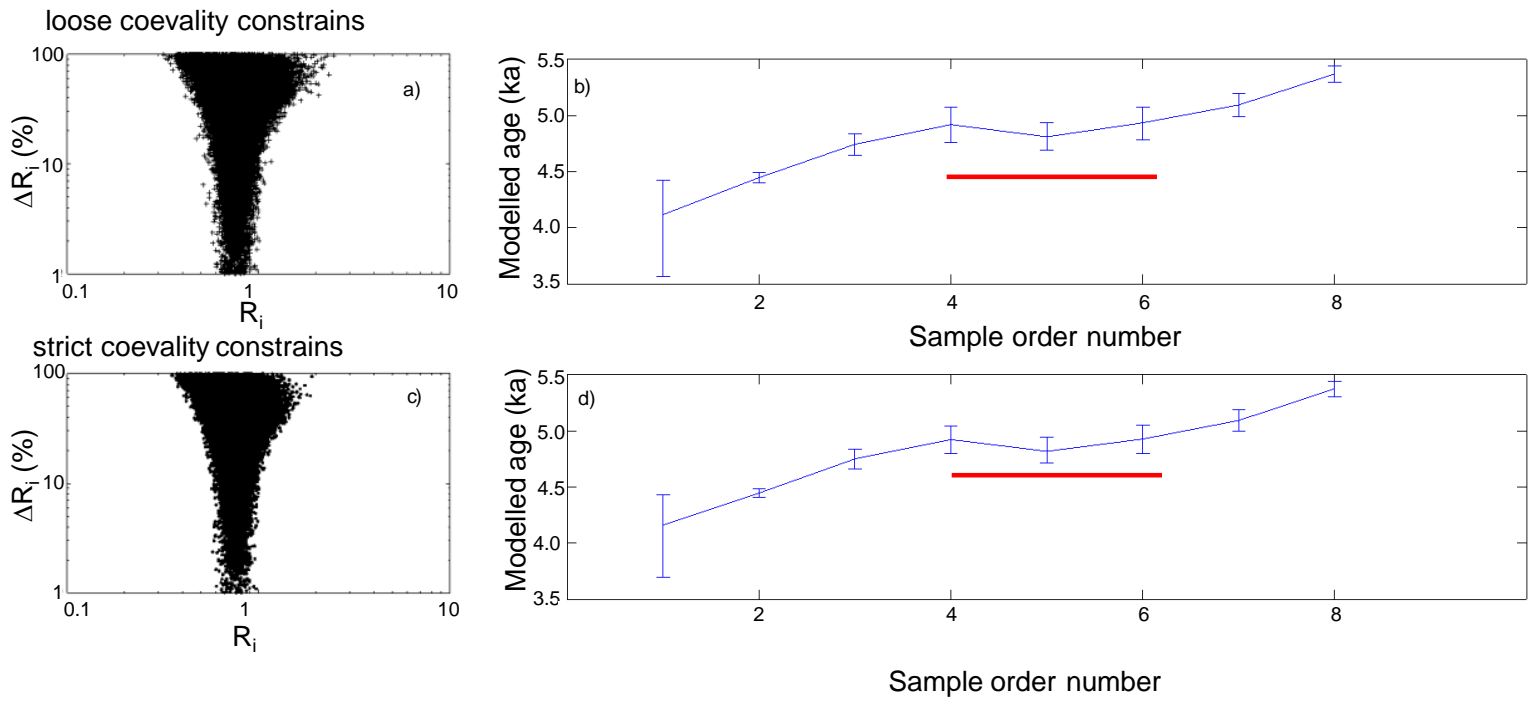

Figure 3 (Rupt du Puits) 
loose coevality constrains
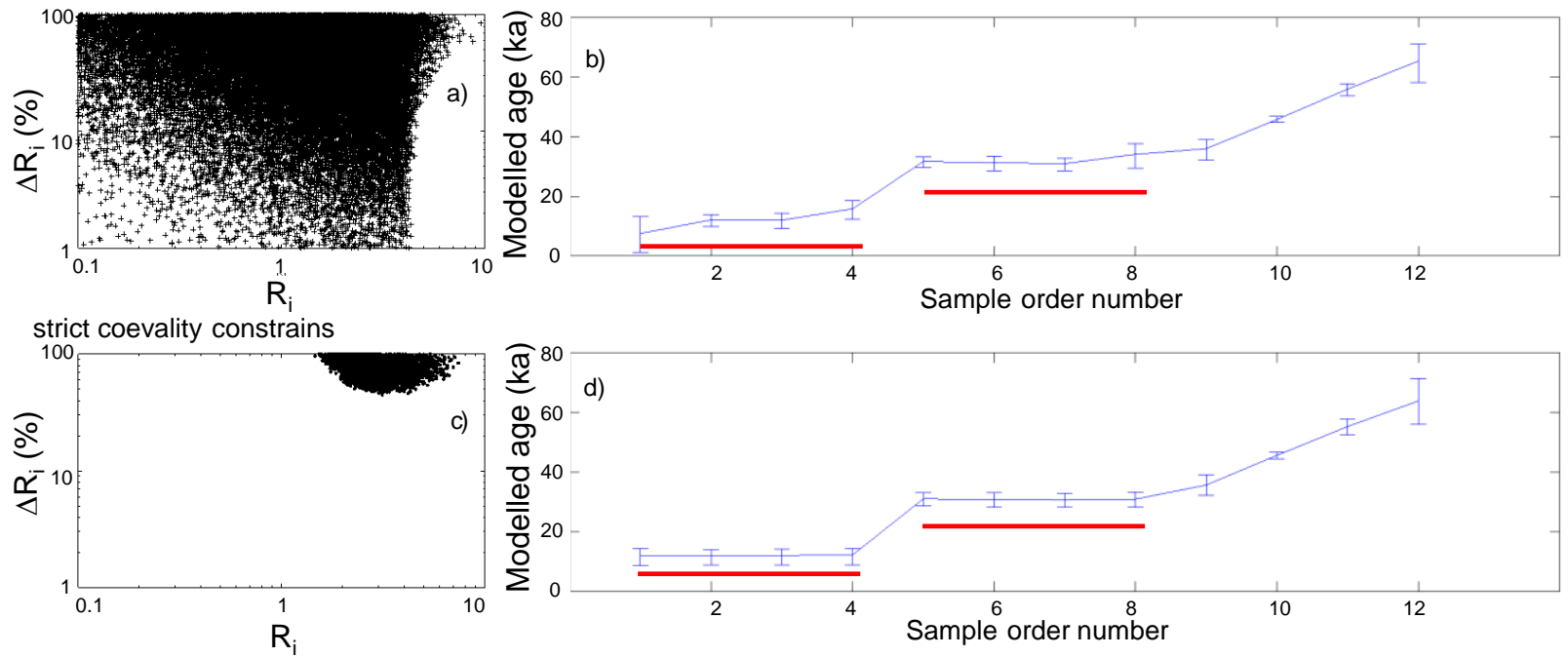

Figure4 (Santo coral core) 

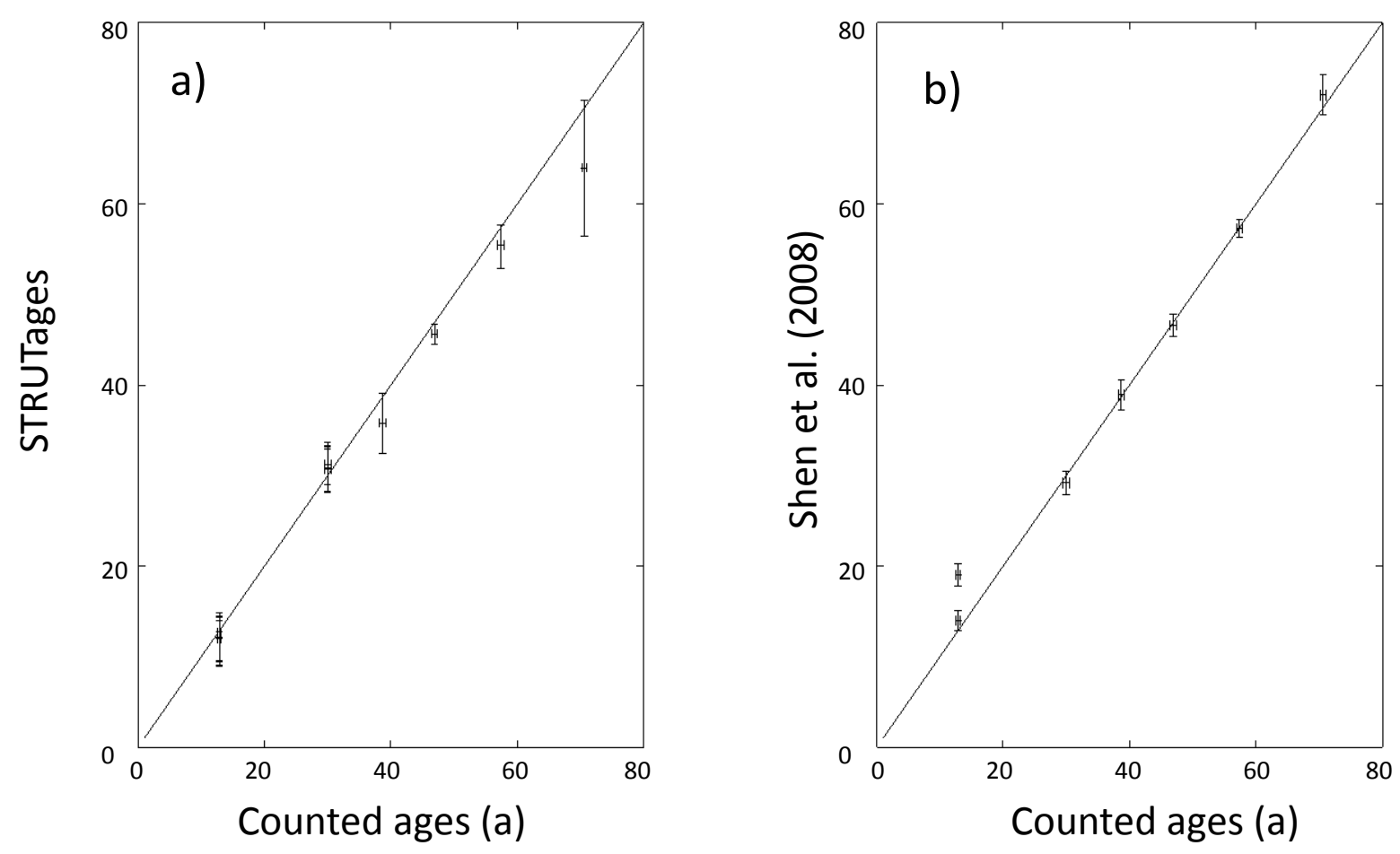

Figure 5 
Published in Quaternary Geochronology, Volume 32, April 2016, Pages 29-39 